\title{
Editorial
}

\section{Climate change: time to redefine our profession}

As the December Copenhagen Summit on climate change ended, the chief negotiator for the 130 'G77' lowerincome countries said that the final document was 'asking Africa to sign a suicide pact'. Greenpeace said: 'The city of Copenhagen is a crime scene tonight, and the guilty men and women are fleeing to the airport'. US President Barack Obama explained that he couldn't stay for the final vote because of 'weather constraints in Washington'. The next day, the International Public Policy Institute said: 'Leaders came to Copenhagen to rewrite history and left having made a few notes in the margin' ${ }^{,(1,2)}$.

The first message of this editorial is that the Copenhagen fiasco was not a chance failure. It was inevitable. The world's currently most powerful politicians and their advisors are not in a position to stop or even slow down climate change. The world's dominant ideology still assumes that more 'development' and 'growth' are essential for human happiness, and indeed also for the electability of political parties. Transnational industries with harmonious interests cannot be controlled by national governments with conflicting interests. World governance is hamstrung by competitive nation-states, all resisting loss of political or economic advantage. All this frustrates achievement of radical, collaborative and equitable change in management of the biosphere. The result is ever-increasing exploitation and destruction of living and physical resources, at levels now known, beyond any reasonable doubt, to be the engine of accelerating climate change ${ }^{(3-5)}$.

\section{What's in store}

Human activity is now making natural homoeostatic systems adjust, and the new settings will not favour the dominant species. Projections indicate that many low-lying Pacific islands may be uninhabitable later this century. Perhaps within the lifetimes of some of us and probably of many of our children, large parts of coastland cities including New York, London, St Petersburg, Rio de Janeiro, Dhaka, Jakarta and Manila, as well as Venice and New Orleans, are projected to become inundated and abandoned, together with low-lying territories such as much of the Netherlands and Bangladesh. As temperatures rise and water tables fall, arable land in semi-arid regions is becoming saltier and drier, another result of overuse and abuse of natural resources ${ }^{(3-5)}$. The economies of large regions within Africa, Australia, North America and Russia may well become irreversibly damaged.
In the meantime, we, as well as our leaders, are conflicted. We - or at least most of us - evidently want more money, more possessions, cheap foreign trips and more scope to spend; and we also now wish for a sustainable world for those who come after us. But collectively we cannot have both.

In the Americas, leaders of the original people often predicted eventual catastrophe. Hopi leaders wrote to President Nixon 40 years ago, saying: 'The white man's desire for material possessions and for power has blinded him to the pain he has caused Mother Earth by his quest for what he calls natural resources... If this continues, Mother Nature will react in such a way that almost all men will suffer the end of life as they know it ${ }^{(6)}$

As it turns out, the warning of the Hopi people was not empty. Nor can those of us who live well above sea-level in privileged settings assume that we will be all right. The effects of climate change are also likely to include uncontrollable migrations of hundreds of millions of people, the impelling of more and more destitute rural populations into city slums, and consequent disruption of systems of governance.

\section{What this means for public health nutrition}

Albert Einstein said: 'We can't solve problems by using the same kind of thinking we used when we created them'. Quite. As consumers and customers, and as members of families and communities, we all can become good examples. We can shop in ways that reduce 'food miles $^{,(7)}$, and we can eat less industrially produced meat. We can turn off the tap when brushing our teeth, heat our homes with solar power, and make a habit of walking and cycling. We know this. We can also speak out.

The second message of this editorial is that public health nutritionists should not be mere spectators of climate change and its consequences. We are also actors. Indeed, the one great chance that climate change can be slowed down depends on all professionals realising that they are involved, and committing to concerted action.

Population increase, depletion of natural resources, and also climate change, require us to think again about the principles and purposes of our discipline. We can take a lead from the new thinking within public health, a revival of its classic tradition. On 1 May last year the World Federation of Public Health Associations proclaimed 
The Istanbul Declaration on the nature and mission of public health ${ }^{(8)}$. Its defining statements include:

- Human health and well-being depend on, and are inseparable from, the health, welfare and maintenance of the living world and the biosphere.

- The determinants of personal and population health are social, economic, political and environmental, as well as behavioural and biological.

- The protection of public goods, including public health, is the prime duty and responsibility of all those responsible for governance at all levels.

This, among others, means us. The prevailing ideology of nutrition science is part of the problem. As with politics and economics, nutrition as taught and practised includes assumptions about the 'growth' and 'development' of the human organism which are decreasingly useful and increasingly reckless. It is time to rewrite the textbooks, radically revise curricula, and let the light shine in. Two examples follow.

One. The social, economic and environmental impacts of industrialised food systems cannot rationally be separated from their biological impacts ${ }^{(9)}$. The deep penetration of transnational food and drink companies into lower-income countries, together with unfair trade, unwise aid and outrageous debt, prevent impoverished countries from protecting and feeding themselves. Further, industrial agriculture now generates around 15-30\% of global greenhouse gases, with livestock and milk production by far the biggest contributors ${ }^{(10)}$. In this context, the notion that substantial amounts of resourcegreedy foods of animal origin produced by industrial methods are desirable, irrespective of their nutrient content, is clearly pernicious.

Two. The idea that humans need a lot of protein, and that protein from animal foods is superior, has shaped global food and nutrition policy and practice for 150 years, and has driven the massive increase in the amount of fuel needed for intensive agriculture. But it is now known that requirements for dietary protein are modest, and that combinations of plant foods, as found in most traditional food systems, are adequate sources of essential amino acids. Climate change means that our profession now has the duty emphatically to renounce the idea that animal protein is supreme, and repeatedly to state that balanced and adequate plant-based diets are essential for the survival of the planet, as well as being better protection against disease.

Since its beginnings in the middle of the last century, public health nutrition has been generally seen as a division of human nutrition, itself usually defined as one of the biological sciences. This concept no longer fits our circumstances. Now is a good time to confirm that public health nutrition is not a subset of clinical nutrition, but an integral part of public health. It then becomes obvious that environmental impact, including climate change and its implications, is and must be at the centre of our learning, teaching, practice and advocacy. In such ways, our profession will be better able to address the agenda of the next climate change summit in Mexico, to be held in December. This will be increasingly reflected in the papers and the editorial contributions published in this journal $^{(11)}$.

Agneta Yngve

Editor-in-Chief

Barrie Margetts

Marilyn Tseng

Roger Hughes

Geoffrey Cannon

Deputy Editors

\section{Acknowledgement}

Thanks to Tony McMichael of the Australian National University, Canberra, who acted as a reviewer.

\section{References}

1. Vidal J, Stratton A \& Goldenberg S (2009) Low targets, goals dropped: Copenhagen ends in failure. The Guardian, 19 December.

2. McKie R (2009) Why I believe that all is not lost - yet. The Guardian, 20 December.

3. Meadows D, Randers J \& Meadows D (2004) Overshoot. In: Limits to Growth. The 30-Year Update, Chapter 1. White River Junction, VT: Chelsea Green Publishing Company.

4. Allen M, Frame D, Frieler K et al. (2009) The exit strategy. Nat Rep Climate Change 30 April, doi:10.1038/climate. 2009.38

5. The New Economics Foundation/The International Institute for Environment and Development (2009) Other Worlds Are Possible. Human Progress in an Age of Climate Change. http://www.neweconomics.org/publications/otherworlds-are-possible (accessed January 2010).

6. Hopi leaders. Letter to President Nixon. Cited in: McLuhan TC (1971) Touch the Earth. A Self-Portrait of Indian Existence. New York: Outerbridge and Dienstfrey.

7. McKie R (2009) Why Britain faces a bleak future of food shortages. The Guardian, 13 December.

8. World Federation of Public Health Associations (2009) The Istanbul Declaration. Health: the First Human Right. http:// www.wfpha.org/2009_Turkey/Istanbul\%20Declaration\%20 and\%20annex\%20(3).pdf (accessed December 2010).

9. The Giessen Declaration (2005) . Public Health Nutrition 6, 783-786.

10. Friel S, Dangour A, Garnett T et al. (2009) Public health benefits of strategies to reduce greenhouse-gas emissions: food and agriculture. Lancet 374, 2016-2025.

11. Sulda H, Coveney J \& Bentley M (2010) An investigation of the ways in which public health nutrition policy and practices can address climate change. Public Health Nutr 13, 304-313. 